\title{
Computer Model for Determining Bank Storage At Hungry Horse Reservoir, Northwestern Montana
}

GEOLOGICAL SURVEY PROAESSIONALAAPER Prepared in cooperation with the Bonneville Power Administration







\section{Computer Model for Determining Bank Storage}

At Hungry Horse Reservoir,

Northwestern Montana

By T. H. THOMPSON

GEOLOGICAL SURVEY PROFESSIONAL PAPER 833

Prepared in cooperation with the

Bonneville Power Administration

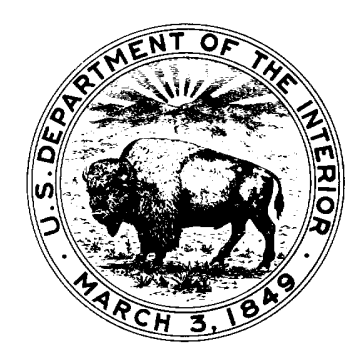

UNITED STATES GOVERNMENT PRINTING OFFICE, WASHINGTON : 1974 
UNITED STATES DEPARTMENT OF THE INTERIOR

ROGERS C. B. MORTON, Secretary

\title{
GEOLOGICAL SURVEY
}

\author{
V. E. McKelvey, Director
}

Library of Congress catalog-card No. 73-600313

For sale by the Superintendent of Documents, U.S. Government Printing Office Washington, D.C. 20402 - Price 65 cents (paper cover)

Stock Number 2401-02485 


\section{CONTENTS}



\section{ILLUSTRATIONS}

FIGURES 1-7. Graphs showing:

1. Comparison of monthly accumulated volumes as computed by the digital model with those computed by Simons' and Rorabaugh's model and water-budget residuals

2. Daily reservoir elevations, yield from bank storage, and cumulative bank-storage volumes for the period December 1, 1959, through March 31, 1960..

3. Cumulative reservoir draft versus cumulative yield from bank storage for the period December 1,1959 , through March 31, 1960 .

4. Model sensitivity to changes in aquifer width

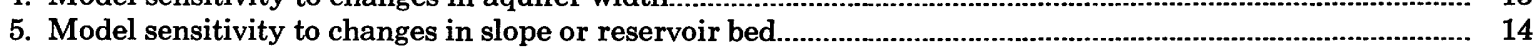

6. Model sensitivity to changes in aquifer transmissivity...........................................................................

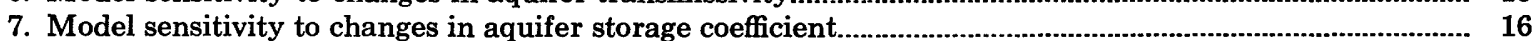

\section{TABLES}

TABLE 1. Cumulative monthend volumes of bank storage computed by the digital model and by Simons' and Rorabaugh's simplified model and the accumulated water-budget residuals

2. Cumulative monthly bank-storage volumes for water years 1952 through 1972.

3. Projected monthend critical rule-curve elevations for Hungry Horse Reservoir for power years 1971-72 through 1980-81

4. Cumulative volumes yielded from bank storage computed by using projected critical rule-curve elevations for power years 1971-72 through 1980-81 


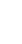




\title{
COMPUTER MODEL FOR DETERMINING BANK STORAGE AT HUNGRY HORSE RESERVOIR, NORTHWESTERN MONTANA
}

\author{
By T. H. ThоMPSON
}

\begin{abstract}
A mathematical model to compute bank storage at Hungry Horse Reservoir, in northwestern Montana, was developed by Simons and Rorabaugh (1971). The model was programmed for solution on a digital computer, using daily reservoir elevations as an input parameter. Monthly accumulated bank-storage volumes for the period October 1951 through September 1972 were calculated.

According to computations using projected rule-curve elevations, an estimated 5.8 percent of the usable reservoir storage volume would be available from bank storage for at-site power generation and downstream benefits if the reservoir was subjected to a long-term, cyclic drawdown.

Several model configurations, other than that recommended by Simons and Rorabaugh (1971), were evaluated. However, the accuracy of the solution using the recommended configuration is within the accuracy limits of the input parameters.

The model sensitivity was evaluated by comparing the results of the model before and after a parameter was changed a fixed percentage while holding the other parameters constant. The model is most sensitive to changes in aquifer width on an annual basis and to changes in the storage coefficient on a seasonal basis.

The computer model can be used to compute bank-storage volumes whenever historical or assumed elevations are available for Hungry Horse Reservoir. The parameters can be changed to estimate bank-storage volumes at other reservoirs having similar geologic, physiographic, and hydrologic conditions.
\end{abstract}

\section{INTRODUCTION}

The hydrology of Hungry Horse Reservoir, in northwestern Montana, was the subject of an extensive study by Simons and Rorabaugh (1971). One of the objectives of their study was to determine accurately the amount of water available for the generation of power at Hungry Horse Dam and for subsequent downstream uses. An apparent imbalance between inflow and outflow at Hungry Horse Reservoir led them to develop a water budget, which included a bank-storage component. Bank storage is defined by Lohman and others $(1972$, p. 12) as the amount of storage change in an aquifer resulting from a change in stage of an adja- cent surface-water body such as a reservoir or river. Simons and Rorabaugh (1971) developed a mathematical model to compute the volume and rate of flow to and from bank storage that would be independent of the water-budget computations of bank storage.

The computation of bank storage by hand using the mathematical model developed by Simons and Rorabaugh is tedious and time consuming. The solution of these equations is greatly facilitated by use of a digital computer. The purpose of this report is to describe the development of a computer program to calculate the volume of bank storage at Hungry Horse Reservoir. The equations and techniques of the model developed by Simons and Rorabaugh are briefly described. The equation and parameters used for the digital-computer solution of bank-storage volume are also described. The sensitivity of the mathematical model to changes in each of the parameters in the equations has been tested and the results are presented in this report.

\section{ACKNOWLEDGMENTS}

This study is part of the continuing program of hydrologic investigations in the Columbia River basin undertaken by the U.S. Geological Survey and the Bonneville Power Administration. The current study was requested and financed by the Bonneville Power Administration.

Valuable assistance and data were furnished by W. D. Simons and M. I. Rorabaugh of the Geological Survey and Mr. Douglas Hanlon of the Bonneville Power Administration.

\section{MODEL DEVELOPMENT}

The theoretical equations for flow of water to and from reservoir bank storage were derived beginning with the analogy between heat flow and ground-water movement with similar boundary conditions. Readers interested in the derivation of these equations may refer to Simons and Rorabaugh (1971, p. 35-38). 


\section{ASSUMED CONDITIONS}

The following assumptions about the reservoir and adjacent aquifer are made. The applicability and reliability of the theoretical method for solution of bankstorage volume depend upon how closely the geometric and hydrologic conditions of the reservoir and aquifer being studied match these assumptions (Simons and Rorabaugh, 1971, p. 34):

1. The unconsolidated material adjacent to the reservoir is the principal aquifer in which bank storage takes place.

2. The aquifer shape can be described as two identical wedges separated by the reservoir.

3. There is a free hydraulic connection through the vertical planes forming the boundaries between the reservoir and aquifer.

4. The vertical planes forming the landward boundaries between the aquifer and the consolidated rocks flanking the valley are parallel to the reservoir boundaries and are impervious to all flow.

5. The planes forming the bottom and the downstream ends of the aquifer are impervious to all flow.

6. There is no vertical recharge to the aquifer.

7. Material is homogeneous and isotropic. Initially, the ground-water level is everywhere at initial reservoir level.

EQUATIONS DEVELOPED BY RORABAUGH

The equations that follow were developed by $M$. I. Rorabaugh for computing bank-storage volume (Simons and Rorabaugh, 1971, p. 38). The terms of the equations (dimensions in parentheses) are also from their report.

\begin{tabular}{cl}
$\begin{array}{c}\text { Symbol } \\
a\end{array}$ & \multicolumn{1}{c}{ Description } \\
$C$ & $\begin{array}{l}\text { Distance from reservoir to valley wall }(L) \\
\left(L T^{-1}\right)\end{array}$ \\
$e$ & Napierian log base $=2.71828 \ldots$ \\
$L$ & $\begin{array}{l}\text { Length of reservoir pool at beginning of any } \\
\text { change }(L)\end{array}$ \\
$m$ & Slope of reservoir bed (dimensionless) \\
$S$ & $\begin{array}{l}\text { Coefficient of storage of the aquifer (dimen- } \\
\text { sionless) }\end{array}$ \\
$T$ & Transmissivity of the aquifer ( $\left.L^{2} T^{-1}\right)$ \\
$t$ & $\begin{array}{l}\text { Time from beginning of change in reservoir } \\
\text { level }(T)\end{array}$ \\
$t_{1}$ & $\begin{array}{l}\text { Duration of a constant rate change in reser- } \\
\text { voir level }(T)\end{array}$
\end{tabular}
Symbol Description
$V$ Volume gain $(+)$ or loss $(-)$ of water in the aquifer $\left(L^{s}\right)$
a $\quad \pi^{2} T / 4 a^{2} S\left(T^{-x}\right)$

For constant rate of drawdown or fill,

$$
\begin{aligned}
& V=2 L C a S t\left\{\left[1-\frac{a^{2} S}{3 T t}+\frac{1}{\alpha t} \frac{8}{\pi^{2}} \sum_{n=1}^{\infty} \frac{e^{-(2 n-1)^{2} \alpha t}}{(2 n-1)^{4}}\right]\right. \\
& -\frac{C t}{L m}\left[\frac{1}{2}-\frac{a^{2} S}{3 T t}+\frac{2}{15}\left(\frac{a^{2} S}{T t}\right)^{2}\right. \\
& \left.\left.-\left(\frac{1}{\alpha t}\right)^{2} \frac{8}{\pi^{2}} \sum_{n=1}^{\infty} \frac{e^{-(2 n-1)^{2} \alpha t}}{(2 n-1)^{6}}\right]\right\} \text {. }
\end{aligned}
$$

For $\mathrm{Tt} / \mathrm{a}^{2} \mathrm{~S} \geq 0.2$, equation 1 can be approximated by

$$
\begin{aligned}
V=2 L C a S t[1 & -\frac{C t}{2 L m}-\frac{a^{2} S}{3 T t}+\frac{C t}{L m} \cdot \frac{a^{2} S}{3 T t} \\
& -\frac{2}{15} \cdot \frac{C t}{L m}\left(\frac{a^{2} S}{T t}\right)^{2} \\
& \left.+\frac{1}{\alpha t}\left(1+\frac{C t}{L m} \cdot \frac{1}{\alpha t}\right) \frac{8}{\pi^{2}} e^{-\alpha t}\right] .
\end{aligned}
$$

For small time, $\mathrm{Tt} / \mathrm{a}^{2} \mathrm{~S}<0.2$, equation 1 can be approximated by

$$
V=2 L C a S t \cdot \frac{4}{3 \sqrt{\pi}} \sqrt{\frac{T t}{a^{2} S}}\left(1-\frac{2 C t}{5 L m}\right) .
$$

For drawdown or fill followed by stationary level,

$$
\begin{aligned}
V_{t \geq t_{1}}= & 2 L C a S t_{1}\left\{1-\frac{C t_{1}}{2 L m}+\frac{1}{\alpha t_{1}} \cdot \frac{8}{\pi^{2}}\right. \\
& {\left[\sum_{n=1}^{\infty} \frac{e^{-(2 n-1)^{2} \alpha t}}{(2 n-1)^{4}}-\left(1-\frac{C t_{1}}{L m}\right)\right.} \\
& \sum_{n=1}^{\infty} \frac{e^{-(2 n-1)^{2} \alpha\left(t-t_{1}\right)}}{(2 n-1)^{4}}+\frac{C t_{1}}{L m} \cdot \frac{1}{\alpha t_{1}} \\
& \left.\left.\sum_{n=1}^{\infty} \frac{e^{-(2 n-1)^{2} \alpha t}-e^{-(2 n-1)^{2} \cdot \alpha\left(t-t_{1}\right)}}{(2 n-1)^{6}}\right]\right\} .
\end{aligned}
$$

For $T t / a^{2} S \geq 0.2$ and $T\left(t-t_{1}\right)-a^{2} S \geq 0.1$, equation 4 can be approximated by

$$
\begin{gathered}
V_{t \geq t_{1}}=2 L C a S t_{1}\left\{1-\frac{C t_{1}}{2 L m}+\left[1+\frac{C t_{1}}{L m} \cdot \frac{1}{\alpha t_{1}}\right.\right. \\
\left.\left.-\left(1-\frac{C t_{1}}{L m}+\frac{C t_{1}}{L m} \cdot \frac{1}{\alpha t_{1}}\right) e^{+\alpha t_{1}}\right] \frac{1}{\alpha t_{1}} \cdot \frac{8}{\pi^{2}} e^{-\alpha t}\right\} .
\end{gathered}
$$

For early times, $\mathrm{Tt} / \mathrm{a}^{2} \mathrm{~S}<0.2$, equation 4 can be approximated by 


$$
\begin{array}{r}
V_{t \geq t_{1}}=2 L C a S \cdot \frac{4}{3 \sqrt{\pi}}\left\{t \sqrt{\frac{T t}{a^{2} S}}\left(1-\frac{2 C t}{5 L m}\right)\right. \\
-\left(t-t_{1}\right) \sqrt{\frac{T\left(t-t_{1}\right)}{a^{2} S}}\left[1-\frac{2 C\left(t-t_{1}\right)}{5 L m}\right] \\
\left.+\left(t-t_{1}\right) \sqrt{\frac{T\left(t-t_{1}\right)}{a^{2} S}}\left(\frac{C t_{1}}{L m}\right)\right\} .
\end{array}
$$

For $\mathrm{Tt} / \mathrm{a}^{2} \mathrm{~S}>0.2$ and $\mathrm{T}\left(\mathrm{t}-\mathrm{t}_{1}\right) / \mathrm{a}^{2} \mathrm{~S}<0.1$,

$$
\begin{aligned}
& V_{t \geq t_{1}}=2 L C a S t\left[1-\frac{C t}{2 L m}-\frac{a^{2} S}{3 T t}+\frac{C t}{L m} \cdot \frac{a^{2} S}{3 T t}\right. \\
&\left.-\frac{2}{15} \cdot \frac{C t}{L m}\left(\frac{a^{2} S}{T t}\right)^{2}+\frac{1}{\alpha t}\left(1+\frac{C t}{L m} \cdot \frac{1}{\alpha t}\right) \frac{8}{\pi^{2}} e^{-\alpha t}\right] \\
&-2 L C a S \cdot \frac{4}{3 \sqrt{\pi}}\left(t-t_{1}\right) \sqrt{\frac{T\left(t-t_{1}\right)}{a^{2} S}}\left[1-\frac{2 C\left(t-t_{1}\right)}{5 L m}\right. \\
&\left.-\frac{C t_{1}}{L m}\right]
\end{aligned}
$$

The calculation of bank-storage volume by equations 1 and 4 was too cumbersome for hand calculation. Therefore, by using equations $2,3,5,6$, and 7 and with the aid of mathematical and graphical shortcuts, averaged reservoir elevations, and rates-of-change trends, bank-storage volume was solved by Simons and Rorabaugh (1971) on a monthly basis.

\section{EQUATIONS USED IN PROGRAM}

Equation 4 was selected to be programmed for computer solution, using daily changes in reservoir elevations and solving for volume on a daily basis. Under this condition the term $t_{1}=1$. Rearranging terms,

$$
\begin{gathered}
V=2 a S\left(L C-\frac{C^{2}}{2 m}\right)+\sum_{n=1}^{\infty}\{L C \\
{\left[2 a S \frac{1}{\alpha} \frac{8}{\pi^{2}} \frac{\left(1-e^{(2 n-1)^{2} \alpha}\right)}{(2 n-1)^{4}}\right]} \\
+\frac{C^{2}}{m}\left(2 a S \frac{1}{\alpha} \frac{8}{\pi^{2}}\right)\left[\frac{e^{(2 n-1)^{2} \alpha}}{(2 n-1)^{4}}\right. \\
\left.\left.+\frac{1}{\alpha} \frac{\left(1-e^{(2 n-1)^{2} \alpha}\right)}{(2 n-1)^{6}}\right]\right\} e^{-(2 n-1)^{2} \alpha t} .
\end{gathered}
$$

Solving for volume in cubic feet per second per day, where $a$ is in feet, $T$ is in square feet per day, $t=$ number of days, let

$$
\begin{aligned}
& A_{01}=2 a S / 86400=a S / 43200, \\
& A_{02}=\frac{2 a S}{86400} \frac{1}{\alpha} \frac{8}{\pi^{2}}=0.81057 \mathrm{~A}_{01} / \alpha, \\
& A_{1 n}=e^{(2 n-1)^{2} \alpha}
\end{aligned}
$$

$$
\begin{aligned}
A_{2 n} & =\frac{2 a S}{86400} \frac{1}{\alpha} \frac{8}{\pi^{2}}\left\{\frac{1-e^{(2 n-1)^{2} \alpha}}{(2 n-1)^{4}}\right\} \\
& =A_{02} \frac{\left(1-A_{1 n}\right)}{(2 n-1)^{4}}
\end{aligned}
$$

and

$$
\begin{aligned}
A_{3 n}= & \frac{2 a S}{86400} \frac{1}{\alpha} \frac{8}{\pi^{2}} \\
& {\left[\frac{e^{(2 n-1)^{2} \alpha}}{(2 n-1)^{4}}+\frac{1}{\alpha} \frac{\left(1-e^{(2 n-1)^{2} \alpha}\right)}{(2 n-1)^{6}}\right] } \\
= & A_{02} \frac{1 n}{(2 n-1)^{4}}+\frac{1}{\alpha} \frac{A_{2 n}}{(2 n-1)^{2}}
\end{aligned}
$$

then

$$
\begin{aligned}
V= & A_{01}\left\{L C-\frac{C^{2}}{2 m}\right\}+\stackrel{\Sigma}{\Sigma}=1^{\infty} \\
& \left\{\left(L C A_{2 n}+\frac{C^{2}}{m} A_{3 n}\right)\left(A_{1 n}\right)^{-t}\right\} .
\end{aligned}
$$

Let

$E_{0}=$ Elevation of the base of the reservoir (ft)

$E_{1}=\begin{gathered}\text { Elevation of reservoir at beginning of } t^{\text {th }} \text { day } \\ \text { (ft) }\end{gathered}$

$E_{2}=$ Elevation of reservoir at end of $t^{\text {th }}$ day (ft)

$C=$ Change in stage during $t^{\text {th }}$ day $=E_{2}-E_{1}(\mathrm{ft})$

$L=$ Reservoir length at beginning of $t^{\text {th }}$ day $=$

$$
\begin{aligned}
& \left(E_{0}-E_{1}\right) / m(\mathrm{ft}) \\
X_{t}= & L C-\frac{C^{2}}{2 m} \\
Y_{t}= & L C \\
Z_{t}= & \frac{C^{2}}{m}
\end{aligned}
$$

then

$V=A_{01} X_{t}+{ }_{n=1}^{\infty}\left\{\left[Y_{t} A_{2 n}+Z_{t} A_{3 n}\right] A_{1 n}{ }^{-t}\right\}$.

When $t=1$,

$V_{t=1}=A_{01} X_{1}+\stackrel{\infty}{\Sigma}=1_{n}\left\{\left[Y_{1} A_{2 n}+Z_{1} A_{3 n}\right] A_{1 n}^{-1}\right\}$. 
At $t=2$ the volume includes the cumulative effect of the changes for day one plus the change for day two, thus

$$
\begin{gathered}
V_{t=2}=A_{01} X_{1}+\sum_{n=1}^{\infty} \\
\left\{\left(Y_{1} A_{2 n} \quad Z_{1} A_{3 n}\right) A_{1 n}-2\right\}+A_{01} X_{2} \\
+{ }_{n=1}^{\infty}\left\{\left(Y_{2} A_{2 n}+Z_{2} A_{3 n}\right) A_{1 n}-1\right\} \\
=A_{01}\left(X_{1}+X_{2}\right)+{ }_{n=1}^{\infty}\left\{\left(\left(Y_{1} A_{2 n}+Z_{1} A_{3 n}\right) A_{1 n}-1\right.\right. \\
\left.\left.+Y_{2} A_{2 n}+Z_{2} A_{3 n}\right) A_{1 n}-1\right\}
\end{gathered}
$$

At $t=3$,

$$
\begin{aligned}
& V_{t=3}=A_{01} X_{1}+\stackrel{\infty}{n}=1^{\infty} \\
& \left.\left\{Y_{1} A_{2 n}+Z_{1} A_{3 n}\right) A_{1 n}{ }^{-3}\right\}+A_{01} X_{2} \\
& +{ }_{n=1}^{\infty}\left\{\left(Y_{2} A_{2 n}+Z_{2} A_{3 n}\right) A_{1 n}^{-2}\right\} \\
& +A_{01} X_{3}+\sum_{n=1}^{\infty}\left\{\left(Y_{3} A_{2 n}+Z_{3} A_{3 n}\right) A_{1 n}-1\right\} \\
& =A_{01}\left(X_{1}+X_{2}+X_{3}\right)+\stackrel{\infty}{\Sigma}_{n} 1 \\
& \left\{\left(\left(\left(Y_{1} A_{2 n}+Z_{1} A_{3 n}\right) A_{1 n}-1\right.\right.\right. \\
& \left.+Y_{2} A_{2 n}+Z_{2} A_{3 n}\right) A_{1 n}-1 \\
& \left.\left.+Y_{3} A_{2 n}+Z_{3} A_{3 n}\right) A_{1 n}{ }^{-1}\right\}
\end{aligned}
$$

at $t=k$,

$$
\begin{aligned}
& V_{t=\mathrm{k}}=\stackrel{k}{\stackrel{k}{\Sigma}} A_{01} X_{t}+\stackrel{k}{\stackrel{k}{\Sigma}} 1 \stackrel{\stackrel{\infty}{=}}{=} 1 \\
& \left\{\left(Y_{t} A_{2 n}+Z_{t} A_{3 n}\right) A_{1 n}-(k-t+1)\right\} \text {. }
\end{aligned}
$$

Equation 21 was solved using from 5 to 30 terms of the infinite series for various $\alpha$ values. For $\alpha$ 's greater than $0.007,10$ terms are sufficient for the $n$ series for an accuracy well within the accuracy of the measurable parameters. Assuming $\stackrel{\Sigma}{\Sigma}=1_{n=1}^{\infty} \sum_{1}$, then the volume at day $t=k$ is approximated by

$$
\begin{gathered}
V_{t=k}=\stackrel{\Sigma}{=}=1_{01}^{k} A_{t}+\sum_{t=}^{k} 1 \\
\left(Y_{t} A_{21}+Z_{t} A_{31}\right) A_{11}-(k-t+1) \\
+\sum_{t=1}^{k}\left(Y_{t} A_{22}+Z_{t} A_{32}\right) A_{12}-(k-t+1) \\
+{ }_{t=1}^{k}\left(Y_{t} A_{23}+Z_{t} A_{33}\right) A_{13}-(k-t+1) \\
+\ldots+\sum_{t=1}^{k}\left(Y_{t} A_{29}+Z_{t} A_{39}\right) A_{19}-(k-t+1) \\
+\sum_{t=1}^{k}\left(Y_{t} A_{210}+Z_{t} A_{310}\right) A_{110}-(k-t+1)
\end{gathered}
$$

Let

$$
\begin{aligned}
& A_{0}={ }_{t=1}^{k} A_{01} X_{t} \\
& A_{1}=\sum_{t=1}^{k}\left(Y_{t} A_{21}+Z_{t} A_{31}\right) A_{11}-(k-t+1) \\
& A_{2}=t \stackrel{k}{=}\left(Y_{t} A_{22}+Z_{t} A_{32}\right) A_{12}-(k-t+1)
\end{aligned}
$$

(Equations for $\mathrm{A}_{3}$ through $\mathrm{A}_{9}$ (26-32) not included)

$$
\begin{aligned}
& A_{10}=\stackrel{k}{\stackrel{k}{\Sigma}} 1 \\
& \left(Y_{t} A_{210}+Z_{t} A_{310}\right) A_{110}-(k-t+1)
\end{aligned}
$$

then

$$
V_{t=\mathrm{k}}=A_{0}+A_{1}+A_{2}+\ldots+A_{10},
$$

where $V_{t}$ is the total cumulative bank storage volume at time $t$. Documentation providing a detailed description of the computer program and its use is in a report by Thompson (1972).

\section{COMPUTATION OF BANK STORAGE}

The following dimensional constants used in the computer program for computing bank storage at Hungry Horse Reservoir are the same as used by Simons and Rorabaugh (1971, p. 38): 


$$
\begin{aligned}
m & =-0.00293 \\
L & =\frac{3057.5-\left(\text { reservoir elev at start of } t^{\text {th }} \text { day }\right) \mathrm{ft}}{-0.00293} \\
a & =851 \text { feet }
\end{aligned}
$$

Simons and Rorabaugh (1971, p. 46-53) described how several sets of storage and transmissivity values were tested in attempting to find a satisfactory single solution of the model. In comparing the computed bank storage with the water-budget residual, they concluded that a single solution would not be adequate. On a seasonal basis, the slow response of bank-storage yield to changes in reservoir stage is needed, but on a short time basis a quick response is needed. They concluded that a combination of two sets of hydrologic constants, allowing both a quick and slow response to reservoir elevation changes, would best describe the aquifer configuration at Hungry Horse Reservoir. The two sets of aquifer constants selected to calculate volumes were storage $(S)$ as 0.15 and transmissivity $(T)$ as $326 \mathrm{ft}^{2}$ per day (called model 2 ) and $S$ as 0.2 and $T$ as 3,710 $\mathrm{ft}^{2}$ per day (called model 4). The results for each set are then combined after multiplying each by a weighting factor as follows:

Volume $=0.8$ model $2+0.32$ model 4.

The aquifer constants and weighting factors were originally selected on the basis of the nature and distribution of coarse and fine sediments in the aquifer adjacent to Hungry Horse Reservoir and then adjusted on the basis of a comparison with the values computed by the water-budget method, where

$$
\text { Bank storage }=\text { outflow }- \text { inflow } \pm \text { change }
$$$$
\text { in reservoir storage. }
$$

The outflow includes the measured flow below the dam, adjusted for local inflow, and computed evaporation from the reservoir surface according to the energy budget method; the inflow consists of both the gaged and estimated ungaged surface flow to the reservoir plus precipitation on the reservoir as measured at the dam.

\section{COMPUTING BANK STORAGE FROM HISTORICAL DATA}

The same hydrologic constants, weighting factors, and model configuration as used in the model recommended by Simons and Rorabaugh (1971) were used with daily changes in stage for the period October 1964 through April 1967 to evaluate equations 22 through 35 on the digital computer. The accumulated volumes were totaled on a monthly basis and are shown in figure 1 and table 1 , along with the monthly totals as solved by Simons and Rorabaugh (1971) with the waterbudget method (eq 36) and the hand solution of equations $2,3,5,6$, and 7 . The results of the computer solution of the model are slightly less than the compu- tations using simplified techniques. These differences may be due to the use by Simons and Rorabaugh of the approximating equations and their assuming straightline hydrographs between breakpoints rather than using daily changes in reservoir stage.

Some of the differences between either of the models and the water budget shown in figure 1 during periods of snowmelt and reservoir filling can be explained as a result of vertical flow to bank storage. Since the model theory assumes horizontal flow from the reservoir to the aquifer, the actual movement to bank storage as terraces are submerged is larger than calculated. This early filling of the aquifer leaves less room for later months. During periods of snowmelt on the exposed reservoir bed, the water enters the aquifer and is delayed in reaching the reservoir, whereas the water budget includes this volume of water as part of the precipitation on the reservoir surface. Also, channel storage between the main inflow gaging station and the head of the reservoir pool and bank storage in this channel is neglected, which accounts for some of the differences between the models and the water budget. Further discussion of errors can be found at the end of the section "Other Model Configurations."

Daily changes in bank-storage volume, as well as cumulative volumes, may be computed by the model on the digital computer. By using daily changes in stage at Hungry Horse Reservoir for the period October 1951 through September 1972, daily changes in bank storage and cumulative volumes were computed with equations 22 through 35 as previously described. The accumulated monthly bank-storage volumes from this computation are shown in table 2.

The effects of step drawdown of the reservoir surface on changes in bank storage are illustrated in figure 2 and 3. During the period December 1, 1959, through March 31, 1960, Hungry Horse Reservoir was drawn down in a series of steps from an elevation of 3,560.5 feet to an elevation of 3,533.0 feet.

Hydrographs of daily reservoir elevations, daily cumulative bank storage volume, and daily yield from bank storage for the period December 1, 1959, through March 31,1960, are shown in figure 2. Daily cumulative reservoir draft (a summation of net change in reservoir elevation) versus daily cumulative yield from bank storage for this period is shown in figure 3 . The points generally increase chronologically from lower left to upper right. Successive days were connected by straight lines. The continuing yield from bank storage during periods when the reservoir elevation was held nearly constant is illustrated by the nearly vertical segments of the line in this figure. 


\section{COMPUTING BANK STORAGE FROM ASSUMED ELEVATIONS}

The use of the model for determining historical values of bank storage on a daily or monthly basis has been demonstrated. The model may also be used for computing bank-storage changes and cumulative volumes for theoretical or projected reservoir-level changes.

An example of this type of application of the model is the determination of the volume of water that would go to and from bank storage under projected or potential reservoir operating rules. The Pacific Northwest Utilities Conference Committee has projected monthend critical rule-curve elevations at Hungry Horse Reservoir for periods of 2 and 4 years for each of the power years (July through June) of 1971-72 through 198081 (D. W. Hanlon, written commun, 1971). The power years July 1971 through June 1972 and July 1972 through June 1973 were based on a critical period length of 2 years' duration, and the subsequent power years through 1980-81 were based on critical periods of 4 years' duration. These theoretical reservoir elevations are given in table 3 . They were determined by system power loads to be met, the assumed facilities available for generation of power, the amount of storage available for flow regulation, and a sequence of projected streamflow occurrences at each damsite. The streamflows used are usually based upon the minimum flow sequences that occurred during the 30 -year historical flow period October 1928 through September 1958. Although the critical rule elevations are designed primarily for power purposes, several other factors are taken into consideration. Among these are flood control, the maintenance of maximum and minimum flows, the fish resource, recreational uses, and pollution abatement. Hence, projected critical rule-curve elevations are the elevations of a particular reservoir that would govern the operation of that reservoir to meet critical water needs during a future time period, assuming a particular sequence of streamflow events occurs.

The projected critical rule-curve elevations begin with an assumed full pool elevation of $3,560.0$ feet on August 15. D. W. Hanlon suggested that prior to that date it be assumed that the reservoir was subjected to a normal filling from an elevation of $3,515.0$ feet on April 15 (written commun., 1971). Bank-storage volume was computed assuming a normal fill and a straight-line hydrograph between projected monthend critical rule-curve elevations (table 3 ) for the 2- and 4-year periods.

The cumulative volumes calculated from bank storage at the end of each critical period by using the projected reservoir elevations as input to the computer model are given in table 4 . Also shown in table 4 are the bank-storage volumes expressed as a percentage of the usable reservoir volume (which is $1,503,400$ cfsdays between elevations $3,560.0$ and $3,336.0 \mathrm{ft}$ ). The result implies that 5.8 percent additional water would be available for power generation at Hungry Horse Reservoir and downstream uses if the reservoir was subjected to a cyclic drawdown over a 2-year or longer period to the minimum pool elevation of $3,336.0$ feet.

\section{OTHER MODEL CONFIGURATIONS}

Several model configurations and various hydrologic constants were evaluated by Simons and Rorabaugh (1971, p. 41-54). They concluded that the bank storage computed by the combination model $2\left(\mathrm{~m}_{2}\right)+0.4$ model $4\left(\mathrm{~m}_{4}\right)$ gave a reasonable match to the field data, but it was judged high because of the high implied storage coefficients ( $S$ of 0.19 for fine till and $S$ of 0.4 for the gravel and sand). The use of the configuration $\mathrm{m}_{2}+0.4 \mathrm{~m}_{4}$ would therefore be more likely to overpredict rather than underpredict the amount of additional water available for power generation. They then recalculated the water budget while assuming that the original gaging records were in error and too large. Assuming a reduction of $0,1,2$, and 5 percent of the flow, the recalculated water-budget residuals were plotted in a double-mass curve versus volumes determined by $\mathrm{m}_{2}+$ $0.4 \mathrm{~m}_{4}$. The slope from the double-mass plots for the 1-percent reduction gave a multiplier of 0.8 to be applied to the model. This configuration of $0.8\left(\mathrm{~m}_{2}+\right.$ $0.4 \mathrm{~m}_{4}$ ) appeared to be the best solution when compared with solutions assuming no reduction in flow and the 2- and 5-percent reductions in flow. The storage coefficients for the configuration $0.8\left(\mathrm{~m}_{2}+0.4 \mathrm{~m}_{4}\right)$ are about 0.15 for 80 percent of the aquifer (fine till) and 0.32 for 20 percent of the aquifer (sand and gravel).

Because of the ease in which the hydrologic constants and model configurations can be changed in the computer, several other model configurations and parameter values were evaluated. The results of the computer solutions were compared with the daily and accumulated monthly water-budget residuals in an attempt to improve the model. However, this line of investigation was terminated because the accuracy of the solution using the model configuration $0.8\left(\mathrm{~m}_{2}+0.4 \mathrm{~m}_{4}\right)$ was within the accuracy limits of the parameter values and water-budget solution.

Some of the larger monthly differences between the computer solution and the water-budget residuals have been previously explained. However, the magnitude of the difference between the computed volume change and actual volume change cannot be measured. Other possible sources of error include inaccuracies in aquifer width, the possibility of bank storage in the material bordering the aquifer, which was assumed imperme- 
able, and errors in elements of the water budget such as the table of reservoir contents.

The accumulated bank-storage volumes computed by the digital computer model and the water-budget residuals at the end of full-pool periods closely correlate on a year-to-year basis. Any improvement in the "fit" between the computer solution and the water-budget residuals would be based upon small changes in the model parameters and water-budget components. These changes would be within the accuracy limitations of the parameters and data, and there would be no assured improvement in the model results.

\section{MODEL SENSITIVITY}

Model (system) sensitivity refers to the change in an output value that can be attributed to a change in one of the system parameters. The sensitivity of the computer model to changes in parameter values provide some guidelines for determining the accuracy required when measuring the parameters. Sensitivity tests also provide some indication of the range of error in the bank-storage volumes computed by the computer model when the reliability of the input parameters are known. To determine the model's sensitivity in computing cumulative bank-storage volume, one parameter was changed a fixed percentage while holding the other parameters constant. The cumulative monthly bankstorage volumes computed after a parameter change $\left(V^{\prime}\right)$, the differences between monthly volumes computed before and after a parameter change $\left(V-V^{\prime}\right)$, and the percentage change in volumes $\left(\frac{V-V^{\prime}}{V} \times 100\right)$ are shown in figures 4 through 7 .

The period October 1964 through April 1967 was selected for the sensitivity test. The comparison of volumes of water from the computer model when the aquifer width $(a)$ was changed \pm 20 percent is shown in figure 4. The comparison before and after the slope (m) was changed \pm 10 percent is shown in figure 5 . The effects of changing transmissivity $(T) \pm 25$ percent are shown in figure 6 , and the effects of changing the storage coefficient $(S) \pm 20$ percent are shown in figure 7 .

The comparison of volumes shown is self-explanatory. It should be noted, however, that although the percentage differences between the monthly volumes before and after the parameter change are large in some cases, the actual differences are not and that a large percentage difference is the result of dividing one small number by another nearly the same. For example, the 70 percent difference in volumes that occurs when aquifer width is increased 20 percent for the month of August 1966 is a result of a difference of cumulative bank-storage volume of only 435 cfs-days; the cumu- lative bank-storage volume before the change was only 621 cfs-days. Thus $435 / 621 \times 100=70$ percent, a large percentage difference but an insignificant actual difference.

It is necessary to exercise care in measuring or estimating all the parameters. The change in slope $(m)$ results in a proportionate change in bank-storage volume throughout the drawdown and fill cycles. The changes in aquifer width $(a)$ result in the largest percentage change on an annual basis, from the beginning of one drawdown to the beginning of the next. When the storage parameter is changed, the largest differences in minimum and maximum accumulated yield from bank storage occur.

There is a shift in the date of occurrence of the maximum and minimum accumulated bank storage when either width, transmissivity, or storage are changed but no shift in date when slope is changed.

The slope parameter can be easily and accurately measured. Of the remaining parameters, the accuracy of the storage coefficient is the most important when the seasonal and monthly changes in bank-storage volume are of interest. However, errors in aquifer width can cause differences in accumulated bank-storage volume that are nearly as much as those as caused by the same percentage error in the storage coefficient.

Transmissivity appears to be the least sensitive of the parameters. This may be misleading, however, since transmissivity has the widest range of possible values of the parameters. Transmissivity is equal to the integration of the hydraulic conductivities across the saturated part of the aquifer perpendicular to the flow path (Lohman and others, 1972, p. 13). According to Davis and DeWiest (1966, p. 164) the average hydraulic conductivities can range from $10^{-2}$ to 10 gallons per day per square foot in a poor aquifer and from $10^{4}$ to $10^{6}$ in a gravel, a possible range of $10^{8}$.

\section{SUMMARY AND CONCLUSIONS}

The theoretical equation and mathematical model developed by Simons and Rorabaugh (1971) for determining bank-storage volume at Hungry Horse Reservoir was programmed and tested on a digital computer. Daily historical reservoir elevations were used as input parameters for computing daily and monthly accumulated bank-storage volumes and changes in bank storage. The monthly total accumulated bank storages as calculated by the digital computer closely match those computed for the same test period by Simons and Rorabaugh (1971) with a desk calculator and mathematical and graphical short cuts. Further attempts at improving the model for computing bank storage at Hungry Horse Reservoir are not warranted because the 
solution developed is well within the accuracy limitations of the data.

Accumulated bank-storage volume was computed using projected rule-curve elevations for the period 1971 through 1981. The results indicate that an additional 5.8 percent of total reservoir volume is available for generation of power and subsequent downstream benefits if the reservoir is subjected to a long-term cyclical drawdown over a 2-year or longer period to a minimum pool elevation of $3,336.0$ feet.

The computer model's sensitivity to changes in each parameter was tested. The model is most sensitive to changes in the aquifer width, with the largest percentage differences occurring near the end of a full pool period. Changes in the storage coefficient result in the largest actual differences in volume that occur during the maximum drawdown periods.

The digital computer model proved to be a useful tool in solving for bank-storage volumes at Hungry Horse Reservoir whenever daily or monthend reservoir elevations (historical or assumed) are available. The model parameters are easily changed. Therefore, the computer model can be used to estimate bank-storage volumes at other reservoirs where historic or assumed reservoir elevations are available, provided the physiographic, hydrologic, and geometric conditions of the reservoir being studied are the same or similar to those assumed for Hungry Horse Reservoir.

\section{SELECTED REFERENCES}

Carslaw, H. S., and Jaeger, J. C., 1959, Conduction of heat in solids: London, Oxford University Press, $510 \mathrm{p}$.

Cooper, H. H., Jr., and Rorabaugh, M. I., 1963, Ground-water movements and bank storage due to flood stages in surface streams: U.S. Geol. Survey Water-Supply Paper 1536-J, p. 343-366.

Davis, S. N., and DeWiest, R. J. M., 1966, Hydrogeology: New York, John Wiley \& Sons, Inc., 463 p.

Hantush, Madhi S., 1961, Discussion of paper by P. P. Rowe; An equation for estimating transmissivity and coefficient of storage from river-level fluctuations: Jour. Geophys. Research, v. 66, no. 4, p. 1310-1311.

Lohman, S. W., and others, 1972, Definitions of selected groundwater terms-Revisions and conceptual refinements: U.S. Geol. Survey Water-Supply Paper 1988, 21 p.

Rorabaugh, M. I., 1964, Estimating changes in bank storage and ground-water contribution of streamflow, in Symposium-Surface water: Internat. Assoc. Sci. Hydrology Pub. 63 p. $432-441$.

Simons, W. D., and Rorabaugh, M. I., 1971, Hydrology of Hungry Horse Reservoir, northwestern Montana: U.S. Geol. Survey Prof. Paper 682, 66 p.

Thompson, T. H., 1972, Reservoir bank storage: Menlo Park, Calif., U.S. Geol. Survey Computer Contr., 29 p.; available only from U.S. Dept. Commerce, Natl. Tech. Inf. Service, Springfield, Va. 22151 as report PB-214 416. 


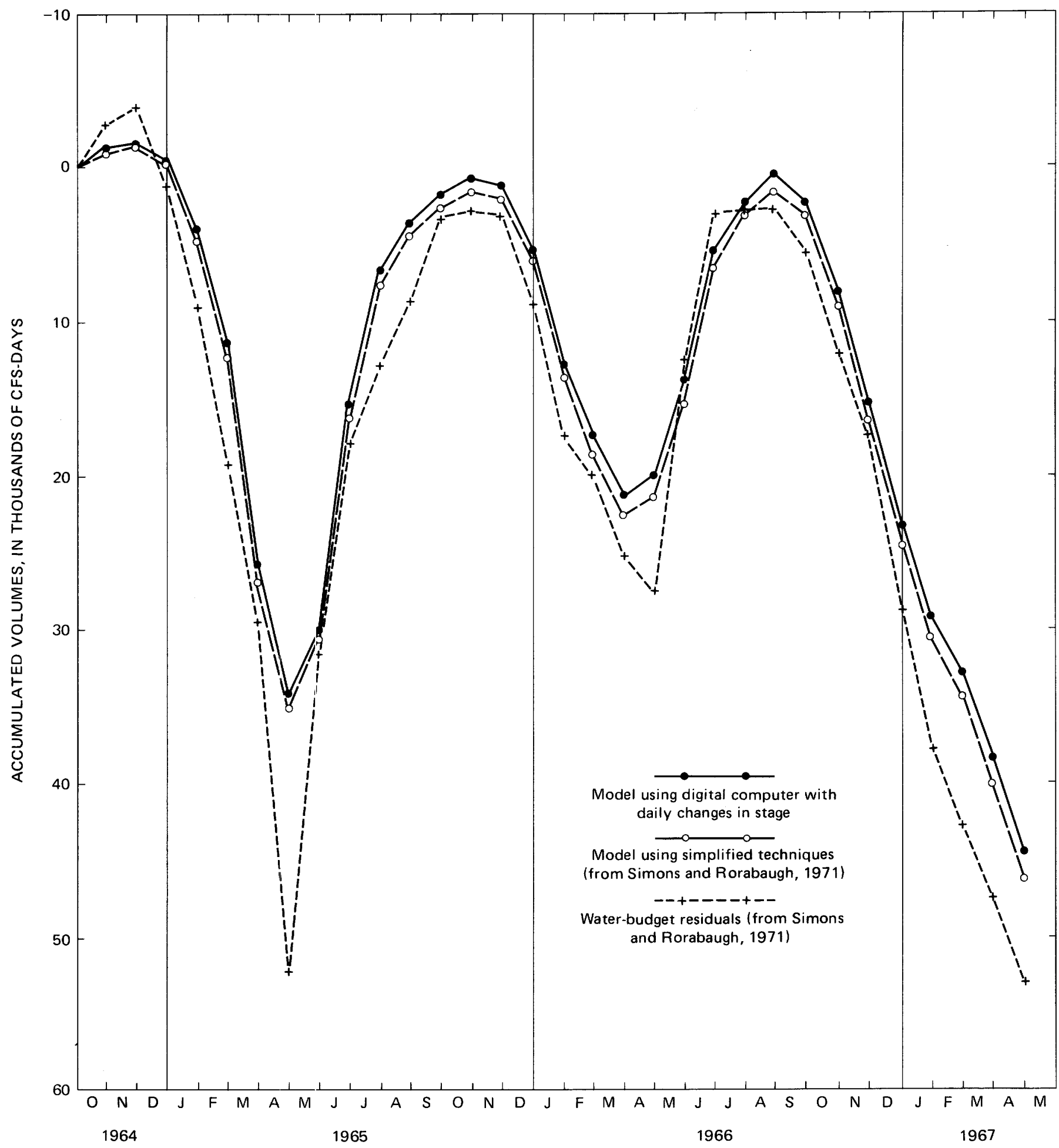

FIGURE 1.-Comparison of monthly accumulated volumes as computed by the digital model with those computed by Simons' and Rorabaugh's model and water-budget residuals. 

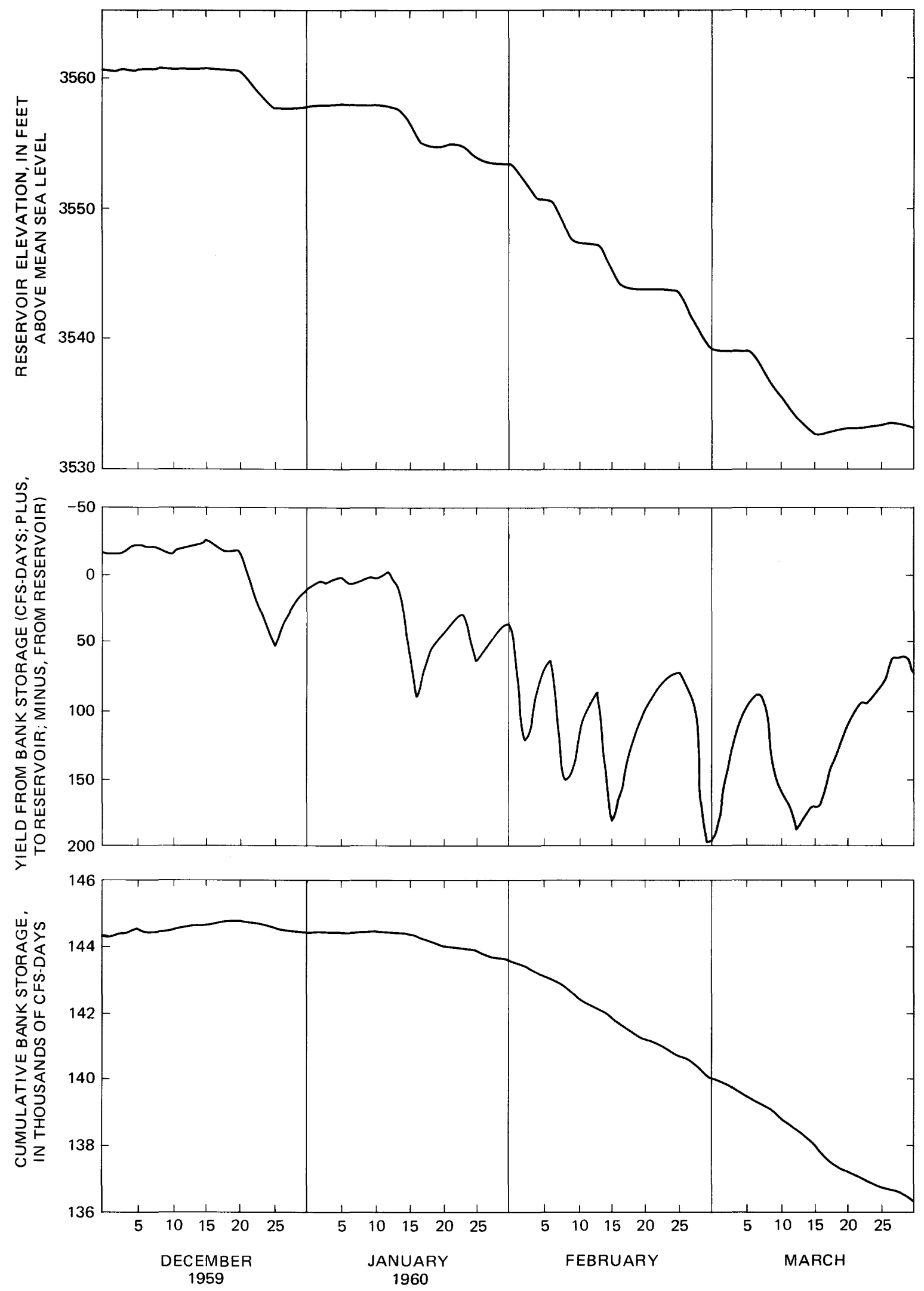

FIGURE 2.-Daily reservoir elevations, yield from bank storage, and cumulative bank-storage volumes for the period December 1, 1959, through March 31, 1960. 


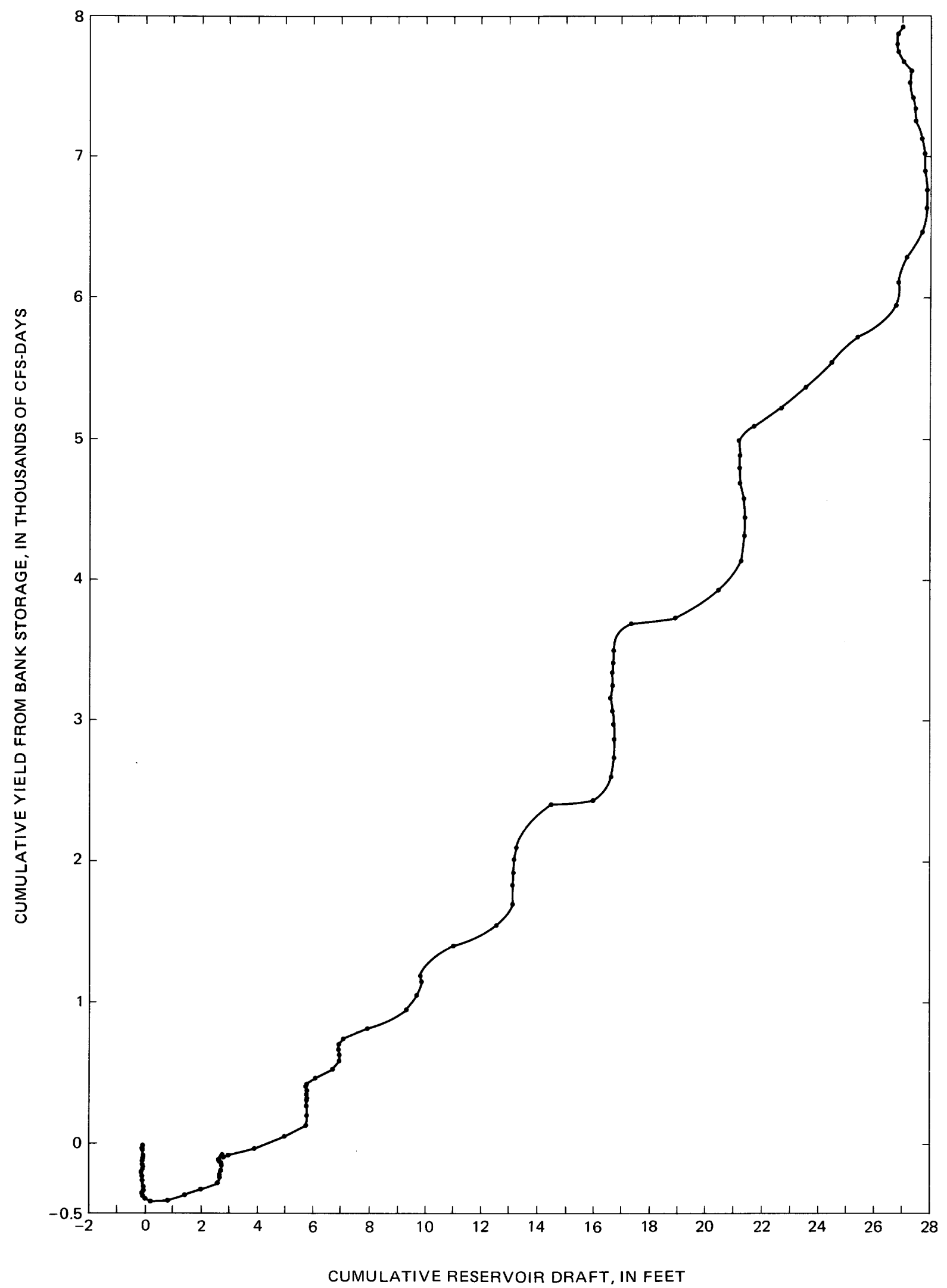

FIGURE 3.-Cumulative reservoir draft versus cumlative yield from bank storage for the period December 1, 1959, through March 31, 1960. Dots represent day-end values and generally accumulate from left to right. 

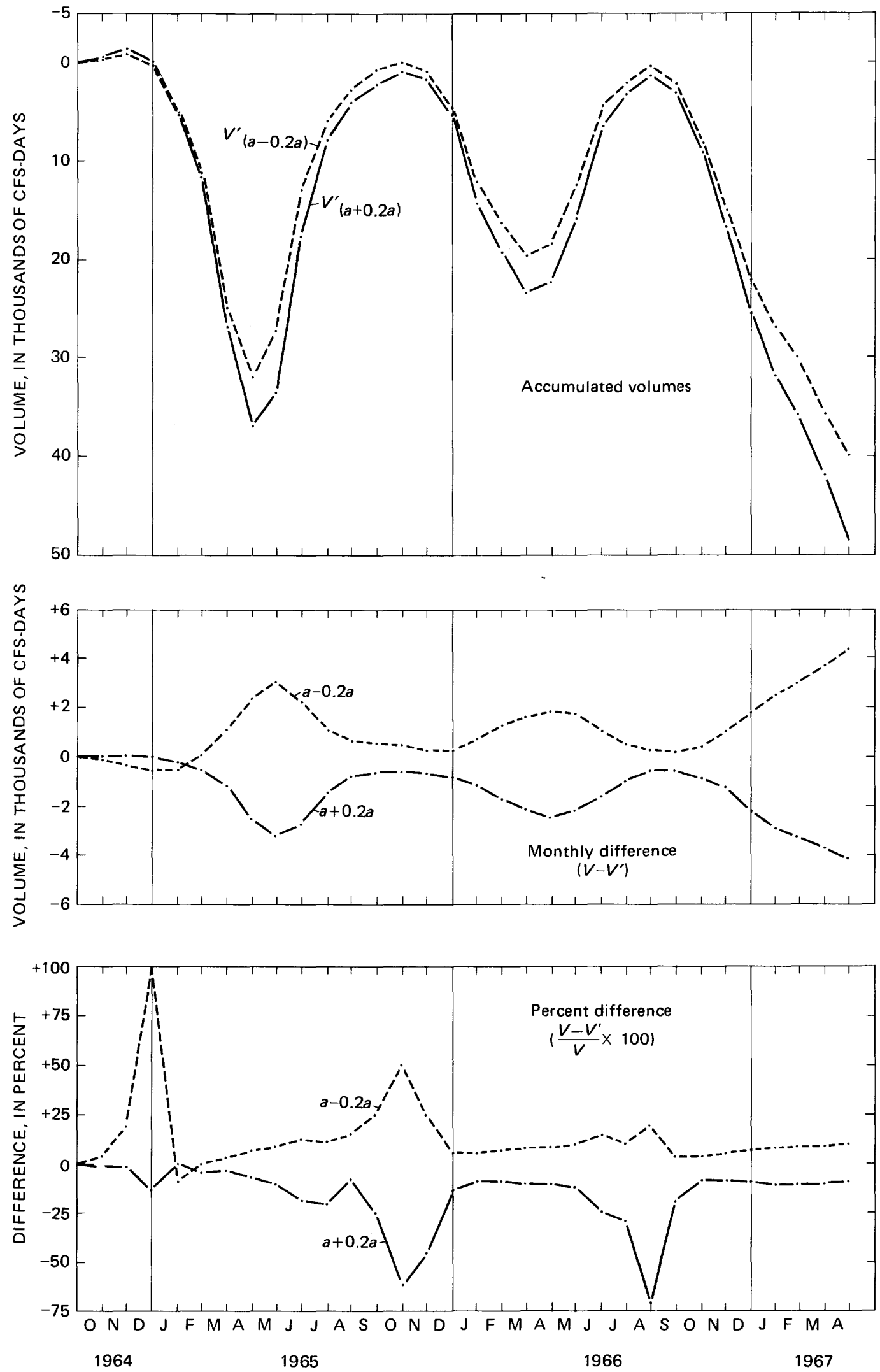

FIGURE 4.-Model sensitivity to changes in aquifer width. Volumes of bank storage computed by model after aquifer width $(a)$ was changed +20 percent and -20 percent; differences between volume before $(V)$ and after $\left(V^{\prime}\right)$ changes in $(a)$; the percent difference before and after $(a)$ was changed +20 percent and -20 percent. 
FIGURES AND TABLES
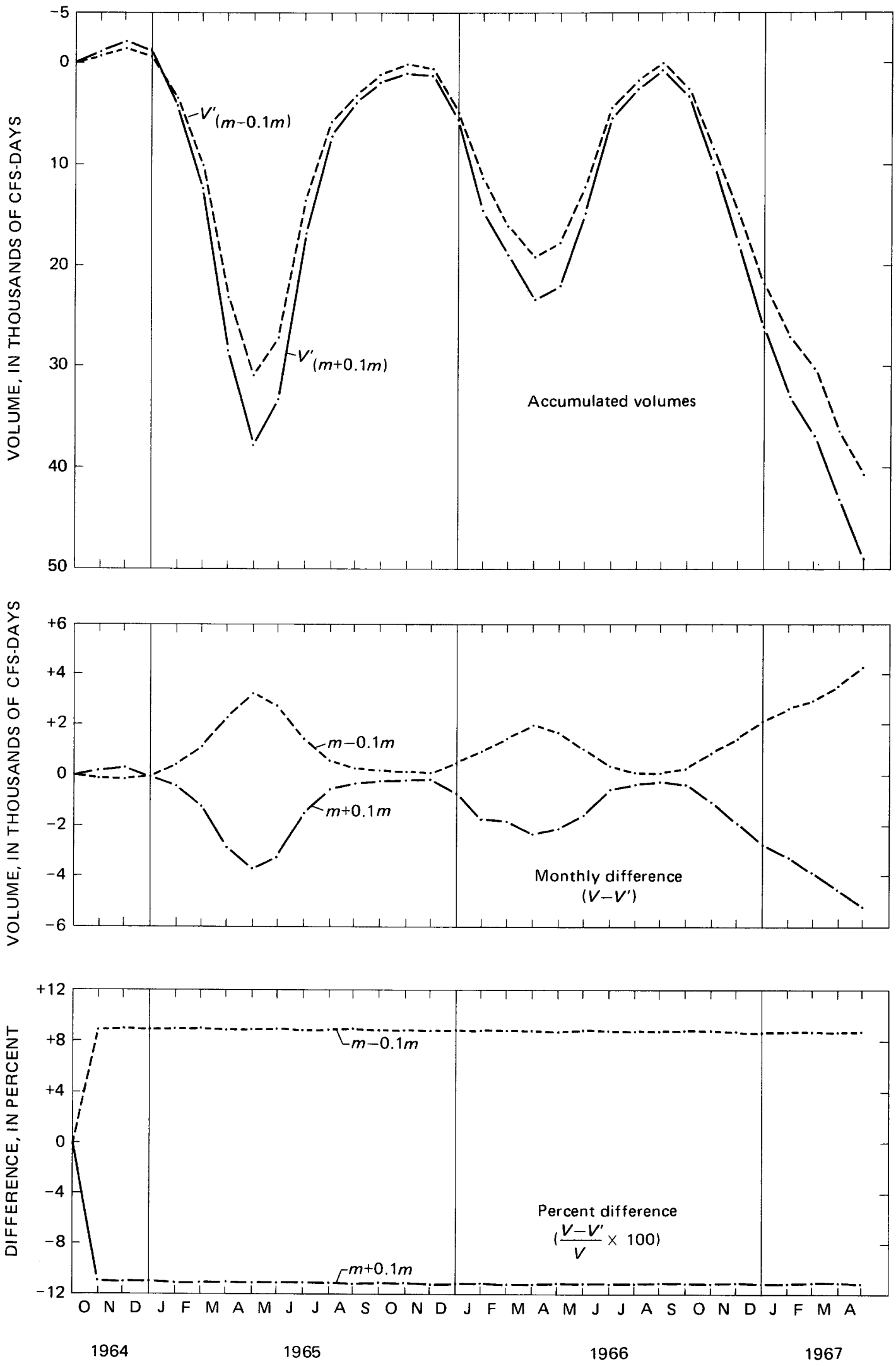

FIGURE 5.-Model sensitivity to changes in slope of reservoir bed. Volumes of bank storage computed by model after slope $(m)$ was changed +10 percent and -10 percent; differences between volumes before $(V)$ and after $\left(V^{\prime}\right)$ changes in $(m)$; the percent difference before and after $(m)$ was changed +10 percent and -10 percent. 

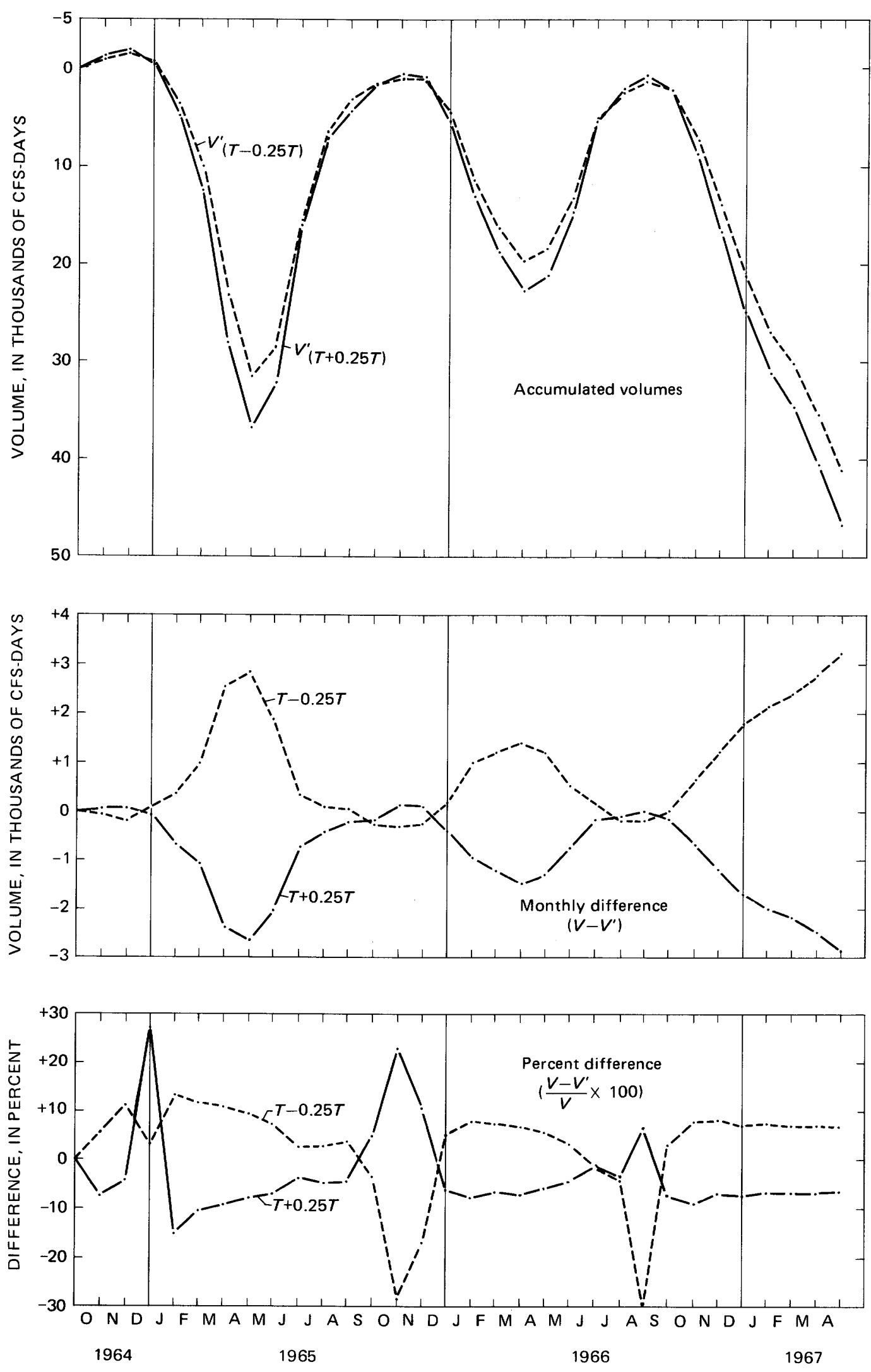

FIGURE 6.-Model sensitivity to changes in aquifer transmissivity. Volumes of bank storage computed by model after transmissivity $(T)$ was changed +25 percent and -25 percent; differences between volumes before $(V)$ and after $\left(V^{\prime}\right)$ changes in $(T)$; the percent difference before and after $(T)$ was changed +25 percent and -25 percent. 

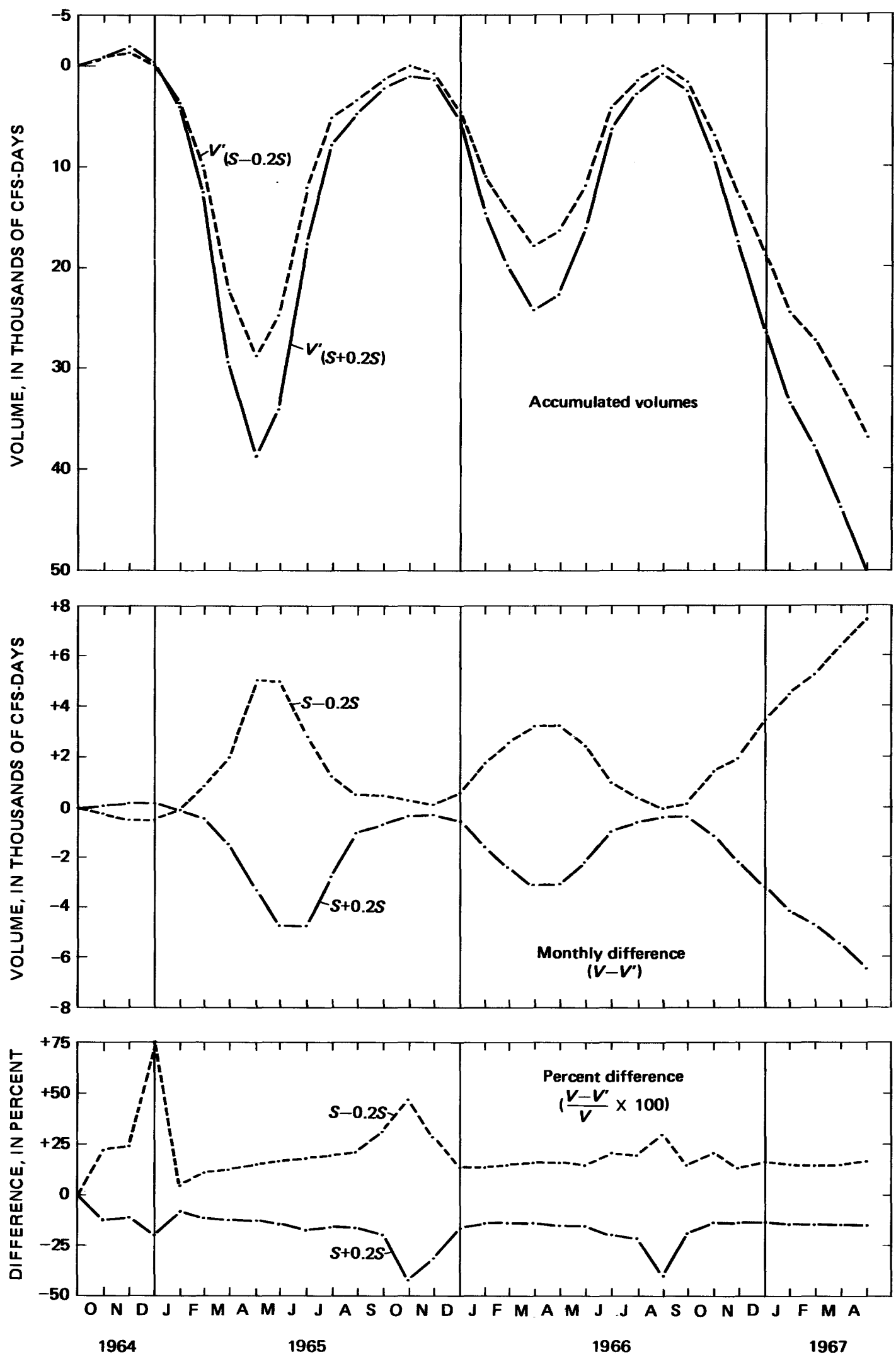

Figures 7.-Model sensitivity to changes in aquifer storage coefficient. Volumes of bank storage computed by model after the storage coeficient (S) was changed +20 percent and -20 percent; differences between volumes before $(V)$ and after $\left(V^{\prime}\right)$ changes in $(S)$; the percent difference before and after $(S)$ was changed +20 percent and -20 percent. 
TABLE 1.-Cumulative monthend volumes of bank storage computed by the digital model $0.8\left(m_{z}+0.4 m_{4}\right)$ and by Simons' and Rorabaugh's simplified model $0.8\left(m_{2}+0.4 m_{4}\right)$ and the accumulated water-budget residuals

[In 1,000 cfs-days; plus, to reservoir; minus, from reservoir]

\begin{tabular}{|c|c|c|c|c|c|c|c|}
\hline Date & $\begin{array}{l}\text { Digital } \\
\text { model }\end{array}$ & $\begin{array}{c}\text { Simons' and } \\
\text { Rorabaugh's model }\end{array}$ & $\begin{array}{l}\text { Water-budget } \\
\text { residual }\end{array}$ & Date & $\begin{array}{l}\text { Digital } \\
\text { model }\end{array}$ & $\begin{array}{c}\text { Simons' and } \\
\text { Rorabaugh's model }\end{array}$ & $\begin{array}{l}\text { Water-budget } \\
\text { residual }\end{array}$ \\
\hline 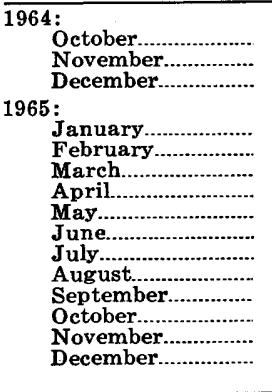 & $\begin{array}{r}-1.2 \\
-1.7 \\
-. .5 \\
4.0 \\
11.3 \\
25.8 \\
34.1 \\
30.0 \\
15.2 \\
6.7 \\
3.6 \\
1.7 \\
.7 \\
1.1 \\
5.1\end{array}$ & $\begin{array}{r}-1.0 \\
-1.6 \\
-. .3 \\
\\
4.6 \\
12.1 \\
26.9 \\
35.0 \\
30.6 \\
16.1 \\
7.5 \\
4.4 \\
2.6 \\
1.6 \\
2.0 \\
6.0\end{array}$ & $\begin{array}{r}-2.8 \\
-4.0 \\
1.0 \\
\\
9.0 \\
19.4 \\
39.7 \\
52.4 \\
31.3 \\
17.9 \\
12.7 \\
8.5 \\
3.0 \\
2.8 \\
3.0 \\
8.8\end{array}$ &  & $\begin{array}{r}12.9 \\
17.5 \\
21.2 \\
19.9 \\
13.8 \\
5.3 \\
2.3 \\
.6 \\
2.3 \\
8.1 \\
15.4 \\
23.3 \\
\\
29.2 \\
32.9 \\
38.4 \\
44.5\end{array}$ & $\begin{array}{r}13.6 \\
18.7 \\
22.4 \\
21.3 \\
15.2 \\
6.5 \\
3.2 \\
1.6 \\
3.2 \\
9.0 \\
16.6 \\
24.6 \\
\\
30.6 \\
34.2 \\
40.0 \\
46.2\end{array}$ & $\begin{array}{r}17.4 \\
20.0 \\
25.2 \\
27.7 \\
12.6 \\
3.0 \\
2.6 \\
2.6 \\
5.7 \\
12.1 \\
17.3 \\
28.9 \\
\\
37.8 \\
42.9 \\
47.5 \\
53.0\end{array}$ \\
\hline
\end{tabular}

TABLE 2.-Cumulative monthly bank-storage volumes for water years 1952 through 1972 [Values $\times 1,000$ cfs-days]

\begin{tabular}{|c|c|c|c|c|c|c|c|c|c|c|c|}
\hline 1 & 1952 & 1953 & 1954 & 1955 & 1956 & 1957 & 1958 & 1959 & 1960 & 1961 & 1962 \\
\hline $\begin{array}{l}\text { October } \ldots . . . . . . . \\
\text { November } \\
\text { December } \\
\text { January }\end{array}$ & $\begin{array}{l}4.7 \\
6.0 \\
4.8 \\
4.6 \\
5.2 \\
5.4\end{array}$ & $\begin{array}{l}57.6 \\
58.2 \\
54.6 \\
51.2 \\
51.4 \\
51.8\end{array}$ & $\begin{array}{l}116.1 \\
116.2 \\
116.0 \\
115.2 \\
111.5 \\
108.1\end{array}$ & $\begin{array}{l}139.7 \\
141.2 \\
139.6 \\
134.0 \\
129.2 \\
122.9\end{array}$ & $\begin{array}{l}142.5 \\
143.2 \\
142.9 \\
140.5 \\
134.3 \\
125.1\end{array}$ & $\begin{array}{l}141.1 \\
139.3 \\
132.7 \\
122.8 \\
115.6 \\
111.1\end{array}$ & $\begin{array}{l}135.5 \\
128.6 \\
120.8 \\
116.8 \\
115.3 \\
114.3\end{array}$ & $\begin{array}{l}142.0 \\
142.6 \\
142.0 \\
138.6 \\
133.6 \\
128.3\end{array}$ & $\begin{array}{l}143.4 \\
144.2 \\
144.3 \\
143.4 \\
140.1 \\
136.3\end{array}$ & $\begin{array}{l}145.0 \\
145.4 \\
145.6 \\
145.7 \\
143.6 \\
138.2\end{array}$ & $\begin{array}{l}142.8 \\
143.3 \\
140.5 \\
133.2 \\
125.1 \\
121.6\end{array}$ \\
\hline 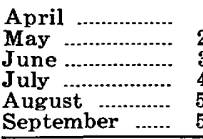 & $\begin{array}{r}8.2 \\
23.2 \\
39.7 \\
47.4 \\
51.9 \\
55.0 \\
\end{array}$ & $\begin{array}{r}54.2 \\
66.4 \\
87.2 \\
100.8 \\
108.0 \\
112.7 \\
\end{array}$ & $\begin{array}{l}103.3 \\
109.5 \\
123.0 \\
131.8 \\
135.4 \\
137.9 \\
\end{array}$ & $\begin{array}{l}118.8 \\
121.9 \\
133.1 \\
138.1 \\
140.2 \\
141.6\end{array}$ & $\begin{array}{l}117.0 \\
122.8 \\
135.3 \\
139.4 \\
141.3 \\
142.1 \\
\end{array}$ & $\begin{array}{l}110.3 \\
121.8 \\
132.3 \\
137.0 \\
139.2 \\
138.0 \\
\end{array}$ & $\begin{array}{l}115.3 \\
123.0 \\
133.1 \\
137.0 \\
139.1 \\
140.7 \\
\end{array}$ & $\begin{array}{l}118.8 \\
120.9 \\
133.8 \\
139.0 \\
141.0 \\
142.4 \\
\end{array}$ & $\begin{array}{l}131.6 \\
132.4 \\
140.0 \\
142.6 \\
143.7 \\
144.4\end{array}$ & $\begin{array}{l}129.4 \\
129.5 \\
139.7 \\
142.4 \\
143.6 \\
143.8 \\
\end{array}$ & $\begin{array}{l}120.9 \\
125.6 \\
135.0 \\
139.1 \\
141.0 \\
142.3 \\
\end{array}$ \\
\hline & & 1963 & 1964 & 1965 & 1966 & 1967 & 1968 & 1969 & 1970 & 1971 & 1972 \\
\hline 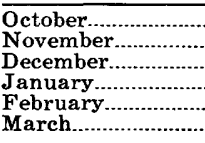 & 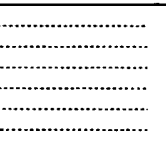 & $\begin{array}{l}143.3 \\
144.1 \\
142.3 \\
136.7 \\
134.0 \\
133.5\end{array}$ & $\begin{array}{l}144.0 \\
144.4 \\
141.2 \\
132.9 \\
126.7 \\
121.1\end{array}$ & $\begin{array}{l}142.8 \\
143.3 \\
142.1 \\
137.6 \\
130.3 \\
115.8\end{array}$ & $\begin{array}{l}140.9 \\
140.5 \\
136.5 \\
128.7 \\
124.1 \\
120.4\end{array}$ & $\begin{array}{l}133.5 \\
126.2 \\
118.3 \\
112.4 \\
108.7 \\
103.2\end{array}$ & $\begin{array}{l}132.6 \\
131.2 \\
125.8 \\
118.4 \\
115.6 \\
115.7\end{array}$ & $\begin{array}{l}141.8 \\
142.7 \\
141.0 \\
137.8 \\
132.1 \\
124.2\end{array}$ & $\begin{array}{l}127.9 \\
124.3 \\
117.4 \\
114.4 \\
113.0 \\
111.6\end{array}$ & $\begin{array}{l}128.3 \\
126.5 \\
122.5 \\
115.5 \\
114.8 \\
112.8\end{array}$ & $\begin{array}{l}136.0 \\
131.3 \\
124.3 \\
116.1 \\
109.4 \\
103.8\end{array}$ \\
\hline 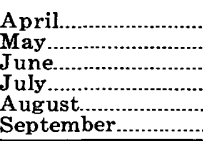 & 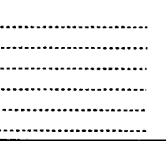 & $\begin{array}{l}130.4 \\
131.2 \\
138.7 \\
141.7 \\
143.0 \\
143.8\end{array}$ & $\begin{array}{l}116.8 \\
119.7 \\
133.2 \\
138.0 \\
140.2 \\
141.6\end{array}$ & $\begin{array}{l}107.5 \\
111.6 \\
126.4 \\
134.9 \\
138.0 \\
140.0\end{array}$ & $\begin{array}{l}121.7 \\
127.8 \\
136.4 \\
139.3 \\
141.0 \\
139.3 \\
\end{array}$ & $\begin{array}{r}97.1 \\
100.6 \\
118.0 \\
129.4 \\
133.9 \\
134.4 \\
\end{array}$ & $\begin{array}{l}116.6 \\
121.5 \\
130.7 \\
136.3 \\
139.1 \\
140.6 \\
\end{array}$ & $\begin{array}{l}118.9 \\
123.2 \\
132.2 \\
138.2 \\
137.4 \\
132.3 \\
\end{array}$ & $\begin{array}{l}107.1 \\
111.0 \\
125.1 \\
133.1 \\
135.2 \\
132.7 \\
\end{array}$ & $\begin{array}{l}105.5 \\
113.2 \\
126.6 \\
133.8 \\
136.9 \\
137.2 \\
\end{array}$ & $\begin{array}{r}95.3 \\
98.7 \\
116.6 \\
127.1 \\
132.9 \\
135.3 \\
\end{array}$ \\
\hline
\end{tabular}

TABLE 3.-Projected monthend (except as noted in August and April) critical rule-curve elevations for Hungry Horse Reservoir for power years 1971-72 through 1980-81

\begin{tabular}{|c|c|c|c|c|c|c|c|c|c|c|c|c|c|c|c|}
\hline $\begin{array}{l}\text { Water } \\
\text { year }\end{array}$ & $\begin{array}{l}\text { Period } \\
\text { length }\end{array}$ & July & $\underset{15}{\text { August }}$ & $\underset{31}{\text { August }}$ & September & October & November & December & January & February & March & $\underset{15}{\text { April }}$ & $\begin{array}{c}\text { April } \\
30\end{array}$ & May & June \\
\hline $\begin{array}{c}1971-72, \\
1972-73 .\end{array}$ & 2 & $\begin{array}{l}3,560.0 \\
3,499.6\end{array}$ & $\begin{array}{l}3,560.0 \\
3,494.2\end{array}$ & $\begin{array}{l}3,560.0 \\
3,488.0\end{array}$ & $\begin{array}{l}3,555.9 \\
3,472.2\end{array}$ & $\begin{array}{l}3,550.2 \\
3,454.9\end{array}$ & $\begin{array}{l}3,539.1 \\
3,434.4\end{array}$ & $\begin{array}{l}3,521.2 \\
3,379.3\end{array}$ & $\begin{array}{l}3,515.9 \\
3,336.0\end{array}$ & $\begin{array}{l}3,515.8 \\
3,336.0\end{array}$ & & $\begin{array}{l}3,515.8 \\
3,336.0\end{array}$ & $\begin{array}{l}3,515.8 \\
3,336.0\end{array}$ & $\begin{array}{l}3,539.6 \\
3,421.2\end{array}$ & $\begin{array}{l}3,527.0 \\
3,468.8\end{array}$ \\
\hline $1973-74 \ldots \ldots$ & $\ldots \quad 4$ & $\begin{array}{c}3,560.0 \\
3,560.0 \\
3,538.8 \\
3,507.3\end{array}$ & $\begin{array}{l}3,560.0 \\
3,560.0 \\
3,538.6 \\
3,502.1\end{array}$ & $\begin{array}{c}3,560.0 \\
3,554.1 \\
3,535.3 \\
3,486.3\end{array}$ & $\begin{array}{l}3,555.6 \\
\mathbf{3}, 554.1 \\
3,529.3 \\
\mathbf{3}, 451.6\end{array}$ & $\begin{array}{l}3,445.1 \\
3,531.5 \\
3,509.9 \\
3,415.9\end{array}$ & $\begin{array}{l}3,526.5 \\
3,506.8 \\
3,485.6 \\
3,360.0\end{array}$ & $\begin{array}{l}3,526.5 \\
3,499.9 \\
3,467.4 \\
3,336.0\end{array}$ & $\begin{array}{l}3,526.5 \\
3,485.5 \\
3,467.4 \\
3,336.0\end{array}$ & $\begin{array}{l}3,526.5 \\
3,480.1 \\
3,462.6 \\
3,336.0\end{array}$ & $\begin{array}{l}3,526.3 \\
3,471.0 \\
3,456.9 \\
3,336.0\end{array}$ & $\begin{array}{l}3,514.6 \\
3,471.0 \\
3,456.9 \\
3,353.7\end{array}$ & $\begin{array}{l}3,514.6 \\
3,489.2 \\
3,456.9 \\
3,378.9\end{array}$ & $\begin{array}{l}3,543.9 \\
3,517.4 \\
3,599.8 \\
3,458.1\end{array}$ & $\begin{array}{l}3,560.0 \\
3,534.9 \\
3,504.6 \\
3,501.0\end{array}$ \\
\hline $1974-75$ & $\ldots 4$ & $\begin{array}{l}3,560.0 \\
3,560.0 \\
3,546.8 \\
3,527.4\end{array}$ & $\begin{array}{l}3,560.0 \\
3,560.0 \\
3,546.8 \\
3,522.8\end{array}$ & $\begin{array}{l}3,560.0 \\
3,560.0 \\
3,544.1 \\
3,509.5\end{array}$ & $\begin{array}{l}3,555.6 \\
3,555.6 \\
3,538.4 \\
3,480.1\end{array}$ & $\begin{array}{l}3,545.1 \\
3,533.1 \\
3,519.8 \\
3,444.6\end{array}$ & $\begin{array}{l}3,525.3 \\
3,508.7 \\
3,497.2 \\
\mathbf{3 , 4 0 3 . 8}\end{array}$ & $\begin{array}{l}3,525.3 \\
3,499.9 \\
3,479.9 \\
3,366.1\end{array}$ & $\begin{array}{l}3,525.3 \\
3,499.6 \\
3,479.9 \\
3,352.0\end{array}$ & $\begin{array}{l}3,525.3 \\
3,494.7 \\
3,475.0 \\
3,336.0\end{array}$ & $\begin{array}{l}3,5 \\
3,4 \\
3,4 \\
3,3\end{array}$ & $\begin{array}{l}3.6 \\
6.3 \\
0.4 \\
3.7\end{array}$ & $\begin{array}{l}3.6 \\
9.9 \\
0.4 \\
8.9\end{array}$ & $\begin{array}{l}3.0 \\
6.4 \\
0.1 \\
8.1\end{array}$ & $\begin{array}{l}3,560.0 \\
3,543.2 \\
3,525.0 \\
3,501.0\end{array}$ \\
\hline $\begin{array}{r}1975-76, \\
1976-77, \\
1977-78 .\end{array}$ & 4 & $\begin{array}{l}3,560.0 \\
3,560.0 \\
3,546.8 \\
3,522.2\end{array}$ & $\begin{array}{l}3,560.0 \\
3,560.0 \\
3,546.8 \\
3,517.4\end{array}$ & $\begin{array}{l}3,560.0 \\
3,560.0 \\
3,544.1 \\
3,506.1\end{array}$ & $\begin{array}{l}3,557.9 \\
3,557.7 \\
3,538.4 \\
\mathbf{3 , 4 7 6 . 1}\end{array}$ & $\begin{array}{l}3,552.6 \\
3,535.5 \\
3,519.8 \\
3,439.3\end{array}$ & $\begin{array}{l}3,539.4 \\
3,511.4 \\
3,497,2 \\
3,400.1\end{array}$ & $\begin{array}{l}3,524.0 \\
3,499.9 \\
3,483.0 \\
3,366.1\end{array}$ & $\begin{array}{l}3,524.0 \\
3,499.6 \\
3,473,0 \\
3,352.0\end{array}$ & $\begin{array}{l}3,524.0 \\
3,494.7 \\
3,468.4 \\
3,336.0\end{array}$ & $\begin{array}{l}3,524.0 \\
3,486.3 \\
3,462.8 \\
3,336.0\end{array}$ & $\begin{array}{l}3,512.1 \\
3,486.3 \\
3,462.8 \\
3,353.7\end{array}$ & $\begin{array}{l}3,512.1 \\
3,499.9 \\
3,462.8 \\
3,378.9\end{array}$ & $\begin{array}{l}\mathbf{3}, 541.7 \\
\mathbf{3}, 526.4 \\
\mathbf{3 , 5 0 4 . 3} \\
3,458.1\end{array}$ & $\begin{array}{l}3,560.0 \\
3,543.2 \\
3,519.7 \\
3,501.0\end{array}$ \\
\hline $\begin{array}{c}1978-79 \\
1980-81 .\end{array}$ & 4 & $\begin{array}{l}3,560.0 \\
3,560.0 \\
3,546.8 \\
3,507.0\end{array}$ & $\begin{array}{l}3,560.0 \\
3,560.0 \\
3,546.8 \\
3,501.8\end{array}$ & $\begin{array}{l}3,560.0 \\
\mathbf{3}, \mathbf{5 6 0 . 0} \\
\mathbf{3}, \mathbf{5 4 4 . 1} \\
\mathbf{3 , 4 8 9 . 3}\end{array}$ & $\begin{array}{l}3,557.9 \\
3,557.7 \\
3,538.4 \\
3,455.5\end{array}$ & $\begin{array}{l}3,552.6 \\
3,535.5 \\
3,519.8 \\
3,412.1\end{array}$ & $\begin{array}{l}\mathbf{3}, 539.4 \\
3,511.4 \\
\mathbf{3 , 4 9 7 . 2} \\
\mathbf{3 , 3 6 3 . 7}\end{array}$ & $\begin{array}{l}3,522.3 \\
3,499.9 \\
3,483.0 \\
3,366.1\end{array}$ & $\begin{array}{l}3,522.3 \\
3,499.6 \\
3,473.0 \\
3,352.0\end{array}$ & $\begin{array}{l}3,522.3 \\
3,494.7 \\
3,468.4 \\
3,336.0\end{array}$ & $\begin{array}{l}3,522.3 \\
3,486.3 \\
3,462.8 \\
3,336.0\end{array}$ & $\begin{array}{l}3,510.4 \\
3,486.3 \\
3,462.8 \\
3,353.7\end{array}$ & $\begin{array}{l}\mathbf{3}, \mathbf{5 1 0 . 4} \\
\mathbf{3}, \mathbf{4 9 9 . 9} \\
\mathbf{3}, \mathbf{4 6 2 . 8} \\
\mathbf{3}, \mathbf{3 7 8 . 9}\end{array}$ & $\begin{array}{l}3,540.2 \\
\mathbf{3 , 5 2 6 . 4} \\
\mathbf{3}, 504.3 \\
\mathbf{3 , 4 5 8 . 1}\end{array}$ & $\begin{array}{l}3,560.0 \\
3,543.2 \\
3,504.3 \\
3,501.0\end{array}$ \\
\hline 1979 & 4 & $\begin{array}{l}3,560.0 \\
3,560.0 \\
3.546 .8 \\
3,510.5\end{array}$ & $\begin{array}{l}3,560.0 \\
3,560.0 \\
3,546.8 \\
3,505.3\end{array}$ & $\begin{array}{l}3,560.0 \\
3,560.0 \\
\mathbf{3 , 5 4 4 . 1} \\
\mathbf{3 , 4 9 3 . 1}\end{array}$ & $\begin{array}{l}3,557.9 \\
3,557.7 \\
3,538.4 \\
3,460.3\end{array}$ & $\begin{array}{l}3,552.6 \\
3,535.5 \\
3,519.8 \\
3,418.5\end{array}$ & $\begin{array}{l}3,539.4 \\
3,511.4 \\
3,497.2 \\
3,372.6\end{array}$ & $\begin{array}{l}3,522.3 \\
3,499.9 \\
3,483.0 \\
3,366.1\end{array}$ & $\begin{array}{l}3,522.3 \\
3,499.6 \\
3,473.0 \\
3,352.0\end{array}$ & $\begin{array}{l}3,522.3 \\
3,494.7 \\
3,468.4 \\
3,336.0\end{array}$ & $\begin{array}{r}\mathbf{3}, 522.3 \\
\mathbf{3}, 486.3 \\
\mathbf{3}, 462.8 \\
3,336.0\end{array}$ & $\begin{array}{l}3,510.4 \\
3,486.3 \\
3,467.0 \\
3,353.7\end{array}$ & $\begin{array}{l}3,510.4 \\
3,499.9 \\
3,467.0 \\
3,378.9\end{array}$ & $\begin{array}{l}3,540.2 \\
3,526.4 \\
3,507.5 \\
3,458.1\end{array}$ & $\begin{array}{l}3,560.0 \\
3,543.2 \\
3,507.7 \\
3,501.0\end{array}$ \\
\hline
\end{tabular}

TABLE 4.-Cumulative volumes yielded from bank storage computed by using projected critical rule-curve elevations for power years 1971-72 through 1980-81

[Usable reservoir volume between elevations of $3,560 \mathrm{ft}$ and 3,336 is $1,503,400 \mathrm{cfs}-\mathrm{days}$ ]

\begin{tabular}{|c|c|c|c|}
\hline $\begin{array}{l}\text { Power } \\
\text { year }\end{array}$ & $\begin{array}{l}\text { Critical } \\
\text { eriod length } \\
\text { (years) }\end{array}$ & $\begin{array}{c}\text { Computed yield } \\
\text { from bank storage } \\
\text { (cfs-days) }\end{array}$ & $\begin{array}{l}\text { Yield from bank storage } \\
\text { divided by total usable } \\
\text { reservoir volume } \\
\text { (percent) }\end{array}$ \\
\hline $\begin{array}{l}1971-72 \ldots \ldots \\
1972-73 \ldots \ldots \\
1973-74 \ldots \\
1974-75 \ldots \\
1975-76 \ldots \ldots\end{array}$ & $\begin{array}{ll}\cdots & 2 \\
\cdots & 2 \\
\cdots & 4 \\
\cdots . . & 4\end{array}$ & $\begin{array}{l}81,518 \\
87,518 \\
89,331 \\
85,098 \\
85,663\end{array}$ & $\begin{array}{l}\mathbf{5 . 8 2} \\
5.82 \\
5.94 \\
5.66 \\
5.70\end{array}$ \\
\hline
\end{tabular}

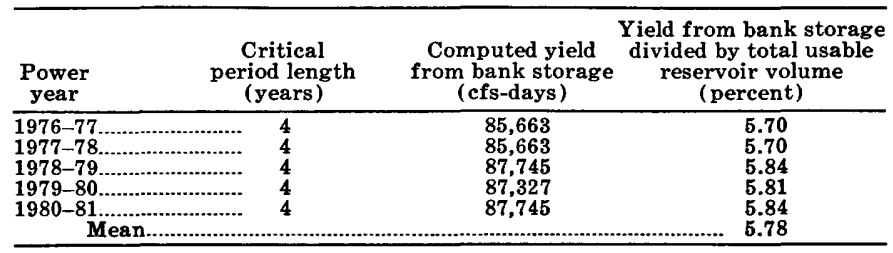

